\title{
Interlinkages among Asian, European and the U.S Stock Markets: A Multivariate Cointegration Analysis
}

\author{
${ }^{*}$ P. Sakthivel ${ }^{1}$, B. Kamaiah ${ }^{2}$ \\ ${ }^{1}$ Gokhale Institute of Politics and Economics Pune, India \\ 2University of Hyderabad, Hyderabad, India \\ *sakthi_hcu@yahoo.co.in
}

\begin{abstract}
The present study attempts to investigate the dynamic interlinkages among the Asian, European and US stock markets. Daily closing prices of twelve stock indices relating to the period from $3^{\text {rd }}$ January 1998 to 30th June 2010 and are used in the analysis. Both short and long run relationships are examined through Johansen-Juselius co integration and Vector Error Correction models (VECM) and Impulse Response Function (IRF). The results of the co integration test show strong co integration relationship across international stock prices indices. The results of the Vector Error Correction model reveal that the US and some of European and Asian Stock markets lead the Indian stock market. Finally, the evidence suggests that the impact of the US market on Indian stock returns is much higher than other way round.
\end{abstract}

Keywords: Johansen and Juselius Co integration, Vector Error Correction Model, Impulse Response Function

\section{Introduction}

Stock markets across the world have become more integrated specifically during the post globalization period. If stock markets are integrated, movements of stock prices are expected to be correlated with one another. There are many reasons why the prices of different stock markets might be correlated. For example, two markets belonging to two different economies might be related through trade and investment. Further, one country's shares are listed on and traded in other international stock exchanges. Therefore, any information regarding the economic fundamentals of one country is transmitted to the other and thus affects the other's stock markets. Many studies have focused on cross-border interdependence between Asian, European and US stock markets including India. The evidence provided by them is mixed, depending on the time and the methodology used in the analysis. The studies by Cheung and Lee (1993); Chan et al. (1992); Hilliard (1979) and Errunza (1985) have found that the equity markets are segmented. While Cheung and Mak (1992) and Masih and Masih (1997a, 1999) have shown evidence that they are strongly integrated. Furstenberg and Jeon (1989) investigated the dynamics of international stock price movements. Their results indicate important role played by the U.S. market in influencing other national markets. Hansda and Ray (2003) examined the interdependence between the BSE/NSE and NASDAQ/NYSE at the aggregate market level and found that evidence of bi-directional causality between the prices of dually listed stocks. This mixed nature of empirical results has motivated further investigate on this issue.

The present study falls in this line of investigation and attempts to investigate the interdependence between the Asian, European and US stock markets using recent time-series. Specifically, the present study uses the multivariate co integration technique based on the work of Johansen and Juselius (1990) to check the number of stochastic trends among the stock indices and the vector error correction model (VECM) to examine the causal relationships among the international stock markets. Present study is justified on ground that the interlinkages of international stock markets are important for portfolio evaluation, derivative pricing, and risk hedging and policymaking. Understanding correlations among stock returns could enable more effective portfolio diversification. Moreover, the political and economic environment and market situation could vary over time, so it is not necessary that the correlations across different markets remain constant over time. Policy makers also are interested in correlations among stock markets because of their implications for the stability of the global financial system. Therefore, it is important to study interdependence across international equity markets. The remainder of this study is structured as follows. Section II provides a review of empirical studies on short run and long run stock market interactions. Section III presents the data and methodology. Section IV deals with the estimation results. Section V provides concluding remarks. 


\section{Literature Review}

In the Indian context, international linkages between Indian and the US and some developed Asian markets like those of Japan, Korea etc has been examined Rao and Naik (1990) using cross-spectral analysis. They found that the relationship of the Indian market with international markets is poor. They concluded that the poor integration of the Indian market with those of US and Japan is because of heavy controls and restrictions on trade and capital flows in India. Recursive estimation technique has been employed to identify the evolution of the linkages. The results for the 1980s indicate that the relaxation of foreign ownership restrictions was not sufficient to attract foreign investors' attention and other factors must have affected the portfolio diversification decision. Results of the 1990s suggest that the relaxation of restrictions might have strengthened international market interrelations. Country Funds have provided access to highly regulated capital markets. In the context of Asian markets of Malaysia, Thailand, Taiwan and South Korea, Zubaidi et al. (2003) investigated the dynamic interrelationships among markets by employing the Johansen co integration and vector error correction models.

The study also examined the impact of financial reforms on these markets. For this purpose, the study divided the sample into two sub-periods: pre-liberalization (1988-91) and post-liberalization (1992-96). The empirical results suggest that all the Asian markets are closely linked with one another and with the world capital markets, namely those of the US and Japan, during the post-liberalization era. Wong et al (2005) investigate the long run equilibrium relationship and short run dynamic interlinkages between the Indian stock market and world's major developed countries' stock markets by using weekly data from the BSE 200 (India), S\&P 500 (US), FTSE 100 (UK) and Nikkei 225 (Japan) from January 1991 to December 2003. Employing the Johansen Multivariate Co integration and Error Correction models, it is found that there is a unidirectional Granger Causality running from the US, UK and Japanese stock markets to the Indian stock market. Finally, the Johansen Maximum Likelihood estimation method suggests that there is only one set of co integrating vectors in the four-variable system. Similarly, Suchismita and Mukherjee (2005) examined the co-movement of the Indian stock market with developed markets like the US, Japanese and other Asian markets using daily data for the period January 1999 to June 2004. Using pair wise Granger Causality and co integration tests, it was found that the US market may not be playing a unique role in the integration of Asian markets.

The issue of equity market integration of the Middle East and North Africa (MENA) countries with an emphasis on international portfolio investment allocation has been investigated by Segot and Lucey (2005) Using four co integration methodologies, they rejected the hypothesis of a stable, long run bivariate relationship between each of these markets and the European Monetary Union, the USA, and a regional benchmark Employing the Multiplier statistic, Berben and Jansen (2005) investigated shifts in correlation patterns among international equity returns at the market level as well as the industry level. Using weekly data from Germany, Japan, the UK and the US for the period 1980-2000, it was found that correlations among the German, UK and US stock markets have doubled, whereas Japanese correlations have remained the same. Both rates of change and speeds of adjustment vary widely across countries and sectors. Khazali et al. (2006) examined empirically whether, and to what extent, equity markets in the Gulf Cooperation Council (GCC) are integrated inter-regionally by employing multivariate co integration. The study used weekly data from October 1994 to December 2003. The results suggest that there exists a common stochastic trend that binds together the four equity markets of Saudi Arabia, Kuwait, Bahrain and Oman. Thus, these four Gulf markets exhibit a robust long-run (equilibrium) relation and any shortrun departures from the equilibrium path will be internally corrected. It may be detriment to note that most of the existing studies have focused on the US and Japanese markets. In the Indian context, there have been relatively few studies examining dynamic interrelationships across international stock markets. These studies show the dominance of the US and Japanese markets and information flows from these markets to India. Therefore, the study makes yet another attempt to investigate cross border interdependence among international stock markets.

\section{Methodology}

Nature and Sources of Data: Daily data were collected from Yahoo finance and DataStream to investigate the interrelations across international stock markets. The study has mainly chosen indices from major developed countries such as United States, United Kingdom, Germany and France and also from Asian countries of Japan, Malaysia, Korea, Singapore, India, Taiwan, and Thailand. It uses most important benchmark index for each country namely, the S\&P500 (US), FTSE 100 (the United Kingdom), 
DAX-30 (Germany), CAC-40 (France), the Nikkei 225 (Japan), SET 50 ( Thailand ) KOSPI (Korea), Kuala Lumpur Composite KLSE (Malaysia), Strait Times Index (Singapore), Taiwan Weighted Index (Taiwan) and the BSE Sensex (India) as an indicator for the Indian stock prices [Table. Data were collected from the daily closing prices of twelve indices for the period $3^{\text {rd }}$ January 1998 to $30^{\text {th }}$ June 2010. All stock prices are converted into natural logarithms to check whether the series are stationary or not.

Table 1: Selected Sample Stock indices

\begin{tabular}{llll}
\hline Serial No & Country & Index & Symbol \\
\hline 1 & Australia & All Ordinaries Shares & AROD \\
2 & India & BSE 30 sensex & BSESN \\
3 & Thailand & SET 50 & SET \\
4 & United Kingdom & FTSE 100 & FTSE \\
5 & Germany & DAX-30 & GDAXI \\
6 & France & CAC-40 & FCHI \\
7 & Japan & Nikkei 225 & NIKKEI \\
8 & Malaysia & Kuala Lumpur Composite & KLSE \\
9 & Singapore & Strait Times Index & STI \\
10 & Korea & KOSPI & KS11 \\
11 & Taiwan & Taiwan Weighted Index & TWI \\
12 & USA & S\&P500 & S\&P \\
\hline
\end{tabular}

The first step in co integration analysis is to determine the order of integration of each price. The present study employs the Augmented Dickey-Fuller (ADF, 1981), and Phillips and Perron (1988) unit root tests. To investigate the long run relationship between the India and other international stock marks, the Multivariate Co integration test is employed. According to the Multivariate Co integration approach, (Johansen and Juselius, 1990), a set of variables is said to be co integrated if they are integrated of the same order and a linear combination of these variables is stationary. Such a linear combination would then point to the existence of a long-term relationship between two or more variables. Further, they tend to move together in the end but may diverge in the short run. This test is based on a vector autoregressive system of non-stationary variables, which is represented as:

$$
\Delta X_{t}=\Gamma_{0}+\sum_{i-1}^{p-i} \Gamma_{i} \Delta X_{t-i}+\Pi X_{t-i}+\varepsilon_{t} \quad \varepsilon \mid \Omega_{\mathrm{t}-1} \sim \operatorname{distr}\left(0_{\mathrm{t}}, \mathrm{H}_{\mathrm{t}}\right)
$$

$X_{t}$ is a vector of $p$ variables, $\Gamma_{0}$ is vector intercepts and $\varepsilon_{t}$ is an independently and identically distributed $\mathrm{n}$ dimensional vector with mean 0 and variance- covariance matrix $\mathrm{H}_{\mathrm{t}}$.

The matrix $\Pi$ in above equation is called the long-run impact matrix and it contains information about the long-run relationship among the variables. The number of co integrating vectors is determined by the rank $(r)$ of the matrix $\Pi$, which indicates the number of co integrating vectors. If $\Pi$ is of full rank, or $r=p$, no co integration is present as all the series are themselves stationary. On the other hand, if $\Pi$ is a null matrix, or $r=0$ then no long-run relationship is present as in the system which would be the usual VAR model in first differences. In the case where $0<r<p$, there exist one or more co integrating relationships among the variables. If co integration is confirmed, then the Granger Causality and impulse response function must be based on the Vector Error Correction (VEC) model (Engle and Granger 1987). The Vector Error Correction model explains the short run relationship between different stock markets and also how these markets tend to make adjustments with one another to the long run equilibrium level. The Impulse Response Function analysis shows that a shock in one market not only affect own market, but also transmits to the other stock markets in the system through the dynamic structure of the VAR.

\section{Results}

Table 2 presents the correlation matrix. It is clear from table that the coefficients of correlation are high for most stock indices. It indicates that most of stock indices are highly correlated to one another. The result also reveals that the S\&P 500 (U.S.A) index is strongly correlated with the European and Asian stock indices. Similarly, Nikkei 225 index is correlated with most of the Asian stock indices including those of India. 
Table 2: Correlation Matrix of Selected Stock Indices

\begin{tabular}{|c|c|c|c|c|c|c|c|c|c|c|c|c|}
\hline Indices & $\begin{array}{l}\text { ALL } \\
\text { OR }\end{array}$ & SE 30 & CAC 40 & DAX & $\begin{array}{l}\text { FSTE } \\
100 \\
\end{array}$ & SET 50 & KLSE & & & STA & TWI & $\begin{array}{l}\text { S\&P } \\
5000 \\
\end{array}$ \\
\hline & 1 & & & & & & & & & & 4576 & 0.8933 \\
\hline & & 1 & & & & & & & & & & \\
\hline & 0.4078 & 059 & 1 & & & & & & & & & 212 \\
\hline & 5509 & 5363 & & & & & & & & & & \\
\hline & & & & & 1 & & & & & & & \\
\hline & 0.8366 & & & & & 1 & & & & & & \\
\hline & & & & & & & 1 & & & & & \\
\hline & 0.8608 & & & & & & & 1 & & & & \\
\hline kkei & 0.8422 & & & & & & & & & & & \\
\hline & 0.8834 & & & & & & & & & 1 & & \\
\hline & 0.4576 & 0.4951 & & & & 0.6534 & 0.4788 & & & & 1 & 0.7749 \\
\hline $8, \mathrm{P}$ & 0.8933 & 0.8636 & 0.9212 & & 0.9296 & 0.6392 & 0.3766 & 0.33018 & 0.8764 & 0.6893 & & 1 \\
\hline
\end{tabular}

Table 3: Descriptive Statistics

\begin{tabular}{|c|c|c|c|c|c|c|c|c|c|c|c|c|}
\hline & ALL OR & BSE & CAC 40 & DAX & FSTE & SET 50 & KLSE & KOSPI & Nikkei & STA & $\begin{array}{l}\text { Taiwan } \\
\text { index }\end{array}$ & $S \& P$ \\
\hline Mean & -0.0014 & -0.0048 & 0.0089 & 0.0003 & 0.0007 & -0.0019 & -0.0022 & -0.00054 & 0.0014 & -0.0014 & $\begin{array}{l}0.003 \\
6.3 \mathrm{E}-\end{array}$ & 0.0004 \\
\hline Median & -0.0004 & -0.0011 & -0.0003 & -0.0007 & -0.0002 & -0.0004 & -0.0002 & -0.0013 & $-7.7 \mathrm{E}-06$ & -0.0026 & 05 & -0.0046 \\
\hline Maximum & 0.0855 & 0.1180 & 0.094 & 0.0743 & 0.0926 & 0.1358 & 0.2415 & 0.1280 & 0.1211 & 0.0921 & 0.099 & 0.0946 \\
\hline Minimum & -0.0536 & -0.1599 & -0.1059 & -0.1079 & -0.0938 & -0.1340 & -0.2081 & -0.1128 & -0.1323 & -0.1287 & -0.0851 & -0.1095 \\
\hline Std. Dev. & 0.0098 & 0.0221 & 0.0157 & 0.0167 & 0.0133 & 0.0183 & 0.01527 & 0.0203 & 0.0163 & 0.01521 & 0.0166 & 0.0238 \\
\hline Skewness & 0.6802 & 0.0918 & 0.0048 & -0.0024 & 0.0957 & -0.1646 & -0.5490 & 0.2077 & 0.2336 & -0.0060 & 0.0926 & 0.1278 \\
\hline $\begin{array}{l}\text { Kurtosis } \\
\text { Jarque- }\end{array}$ & 10.695 & 8.0432 & 7.5913 & 6.7889 & 8.4988 & 9.7351 & 57.607 & 6.5230 & 8.7506 & 9.4244 & 5.1955 & 10.285 \\
\hline Bera & 7377.73 & 3010.55 & 2546.36 & 1734.13 & 3656.823 & 5405.31 & 352018.4 & 1420.44 & 3912.83 & 4952.83 & 570.43 & 6396.31 \\
\hline Probability & 0.0000 & 0.0000 & 0.0000 & 0.0000 & 0.0000 & 0.0000 & 0.0000 & 0.0000 & 0.0000 & 0.0000 & 0.0000 & 0.0000 \\
\hline $\begin{array}{l}\text { Sum } \\
\text { Sum Sq. }\end{array}$ & -0.4087 & -1.3668 & 0.0239 & -0.0921 & 0.2138 & -0.5427 & -0.6312 & -1.4827 & 0.4067 & -0.42969 & 0.2217 & 0.06092 \\
\hline Dev. & 0.2837 & 0.9355 & 0.7169 & 0.8161 & 0.5164 & 0.9554 & 0.6608 & 1.1217 & 0.7496 & 0.6661 & 0.7837 & 0.5523 \\
\hline
\end{tabular}

Table 3 provides summary statistics, such as the sample mean, minimum, maximum, median, standard deviation, skewness, kurtosis and the Jarque- Bera tests and p-values, for the selected indices return series. The daily mean returns for most of the indices are positive, except in the case of All Ordinaries Shares, BSE 30 sensex and Straits Times Index. The standard deviation of S\&P 500, FTSE 100 and NIKKEI 225 is higher among all the stock indices. This implies that higher volatility is observed in these three markets compared to with others. The positive skewness coefficient for most stock indices implies that the frequency distribution of the return series is positively skewed or has longer tails to the right The kurtosis value exceeds more than three for most of the stock indices, which shows that the distribution of stock indices returns is leptokurtic or thick-tailed during the sample period. The JB statistics are statistically highly significant and hence we reject the null hypothesis of a normal distribution of the return series. It indicates that most of the stock indices return series deviate from normal distribution.

Table 4: Augmented Dickey-Fuller Test Statistics

\begin{tabular}{lllll}
\hline Index & Levels & P. Value & First Differences & P. Value \\
\hline All Ordinary Shares & -0.5893 & 0.870 & $-55.548^{*}$ & 0.000 \\
BSE 30 Index & -1.3711 & 0.597 & $-49.541^{*}$ & 0.000 \\
CAC 40 Index & -1.737 & 0.411 & $-26.279^{*}$ & 0.000 \\
DAX-Index & -1.6440 & 0.459 & $-54.795^{*}$ & 0.000 \\
FSTE 100 Index & -2.0215 & 0.277 & $-22.312^{*}$ & 0.000 \\
SET 50 & -1.6599 & 0.4516 & $-52.793^{*}$ & 0.000 \\
KLSE Composite Index & -14316 & 0.568 & -22.642 & 0.000 \\
KOSPI Index & -0.2116 & 0.934 & $-50.039^{*}$ & 0.000 \\
NIKKEI 225 Index & -1.862 & 0.350 & -54.941 & 0.000 \\
Straits Times Index & -1.4045 & 0.5816 & $-49.427^{*}$ & 0.000 \\
Taiwan Weighted & -1.8492 & 6.356 & $-50.726^{*}$ & 0.000 \\
S\&P 500 INDEX & -2.038 & 0.270 & $-42.643^{*}$ & 0.000 \\
\hline
\end{tabular}

* indicates that unit root rejection of null hypotheses 
Table 4 presents the results of the unit root tests. The results of the ADF test show that the presence of a unit root cannot be rejected for most of the stock indices at level forms. However, taking first differences of the return series for stock indices, the null hypothesis of a unit root is rejected. These results show that not all stock indices can reject the presence of a unit root, which is non-stationary in the levels, but stationary in first differences. Similar results, observed for the Phillips-Perron test are given in Table 5.

Table 5: Phillips-Perron Test Statistics

\begin{tabular}{lllll}
\hline Index & Levels & P. Value & First Differences & P. Value \\
\hline All Ordinaries Shares & -0.5314 & 0.882 & $-55.487^{*}$ & 0.000 \\
BSE 30 sensex & -1.316 & 0.624 & $-49.471^{*}$ & 0.000 \\
CAC 40 Index & -1.734 & 0.413 & $-55.593^{*}$ & 0.000 \\
DAX-Index & -1.589 & 0.487 & $-54.759^{*}$ & 0.000 \\
FSTE 100 Index & -2.163 & 0.220 & $-56.120^{*}$ & 0.000 \\
SET 50 & -1.629 & 0.407 & $-52.789^{*}$ & 0.000 \\
KLSE Composite Index & -1.403 & 0.582 & $-51.350^{*}$ & 0.000 \\
KOSPI Index & -0.145 & 0.942 & $-50.018^{*}$ & 0.000 \\
NIKKEI 225 Index & -1722 & 0.419 & $-55.199^{*}$ & 0.000 \\
Straits Times Index & -1.397 & 0.585 & $-49.484^{*}$ & 0.000 \\
Taiwan Weighted & -1.939 & 0.314 & $50.791^{*}$ & 0.000 \\
S\&P 500 INDEX & -2.066 & 0.258 & $-58.745^{*}$ & 0.000 \\
\hline
\end{tabular}

* indicates that unit root rejection of null hypotheses

In the next step, the study employs the Johansen and Juselius co integration technique to test for a long run equilibrium relationship among the Asian, European and US stock markets. Johansen and Juselius procedures are sensitive to the choice of lag length for the VAR model and orders of integration of the variables entering each of the VAR models. Hence, the study has selected lag 2 based on Akaike Information Criteria (AIC), Final Prediction Error (FPE) and Schwarz Information Criteria (SIP). Table 6 provides results of the co integration test. They suggest that the null hypothesis of co integrating vectors $(\mathrm{r}=0)$ under both trace and maximum eigen value of tests has been rejected. However, trace and maximum eigen statistic tests reveal the existence of six co integrating vectors, which cannot reject the null hypothesis of a co integrating relationship at the 5 percent level of significance. It implies that there is a stable long run relationship among stock prices across the world. The results support the hypothesis that most stock price indices across the world move together in the end. Table 7 presents the results of VEC Model. The coefficient of Error Correction Term for, SET 50, BSE 30, CAC-40, KOPSI, Taiwan Weighted Index and All Ordinaries Shares are found to be statistically significant. It implies that these markets share the forces of short-run adjustment to long-run equilibrium. In other words, whenever stock indices (SET 50, BSE 30, CAC-40, KOPSI, Taiwan Weighted Index and All Ordinaries Shares) deviates from equilibrium level, other six markets (US, Germany, Japan, Malaysia, FSTE 100 and Singapore) tend to correct back to towards a long run equilibrium level. These results show that stock markets such as those of the US, Germany, Japan, Malaysia and Singapore lead other markets including India

Table 6: Johansen Co integration Test

\begin{tabular}{lcccc}
\hline \multicolumn{1}{l}{ Unrestricted Co integration Rank Test (Maximum Eigen value) } \\
$\begin{array}{l}\text { Hypothesized } \\
\text { No. CVs }\end{array}$ & $\begin{array}{c}\text { Trace } \\
\text { Statistic }\end{array}$ & $\begin{array}{c}\text { Max-Eigen } \\
\text { Statistic }\end{array}$ & $\begin{array}{c}\mathbf{0 . 0 5} \\
\text { Critical Value }\end{array}$ & Prob.** $^{* *}$ \\
\hline None $^{*}$ & 0.054678 & 152.2148 & 76.57843 & 0.0000 \\
At most $1^{*}$ & 0.044643 & 123.6301 & 70.53513 & 0.0000 \\
At most 2 & 0.035177 & 96.93798 & 64.50472 & 0.0000 \\
At most 3 & 0.030585 & 84.08713 & 58.43354 & 0.0000 \\
At most 4 & 0.025825 & 70.82640 & 52.36261 & 0.0003 \\
At most 5 & 0.018268 & 49.90935 & 46.23142 & 0.0194 \\
At most 6 & 0.011349 & 30.89750 & 40.07757 & 0.3669 \\
At most 7 & 0.009212 & 25.05170 & 33.87687 & 0.3815 \\
At most 8 & 0.006745 & 18.32040 & 27.58434 & 0.4687 \\
At most 9 & 0.004719 & 12.80464 & 21.13162 & 0.4704 \\
At most 10 & 0.000885 & 2.397832 & 14.26460 & 0.9785 \\
At most 11 & 0.000731 & 1.978661 & 3.841466 & 0.1595
\end{tabular}

Max-eigenvalue test indicates 6 co integrating Vector at the 0.05 level of Significance 


\begin{tabular}{lcccc}
\hline \multicolumn{5}{l}{ Unrestricted Co integration Rank Test (Trace Value) } \\
None $^{*}$ & 0.054678 & 669.0565 & 334.9837 & 0.0000 \\
At most $1 *$ & 0.044643 & 516.8417 & 285.1425 & 0.0000 \\
At most $2^{*}$ & 0.035177 & 393.2116 & 239.2354 & 0.0000 \\
At most $3 *$ & 0.030585 & 296.2736 & 197.3709 & 0.0000 \\
At most $4 *$ & 0.025825 & 212.1865 & 159.5297 & 0.0000 \\
At most 5 & 0.018268 & 141.3601 & 125.6154 & 0.0038 \\
At most 6 & 0.011349 & 91.45073 & 95.75366 & 0.0953 \\
At most 7 & 0.009212 & 60.55323 & 69.81889 & 0.2188 \\
At most 8 & 0.006745 & 35.50153 & 47.85613 & 0.4218 \\
At most 9 & 0.004719 & 17.18113 & 29.79707 & 0.6266 \\
At most 10 & 0.000885 & 4.376493 & 15.49471 & 0.8709 \\
At most 11 & 0.000731 & 1.978661 & 3.841466 & 0.1595 \\
At most 12 & 0.000841 & & \\
\hline Trace test indicates 6 co integrating Vector at the 0.05 level of Significance \\
* denotes rejection of the hypothesis at the 0.05 level \\
**MacKinnon-Haug-Michelis (1999) p-values
\end{tabular}

Table 7: Results of Vector Error Correction Model

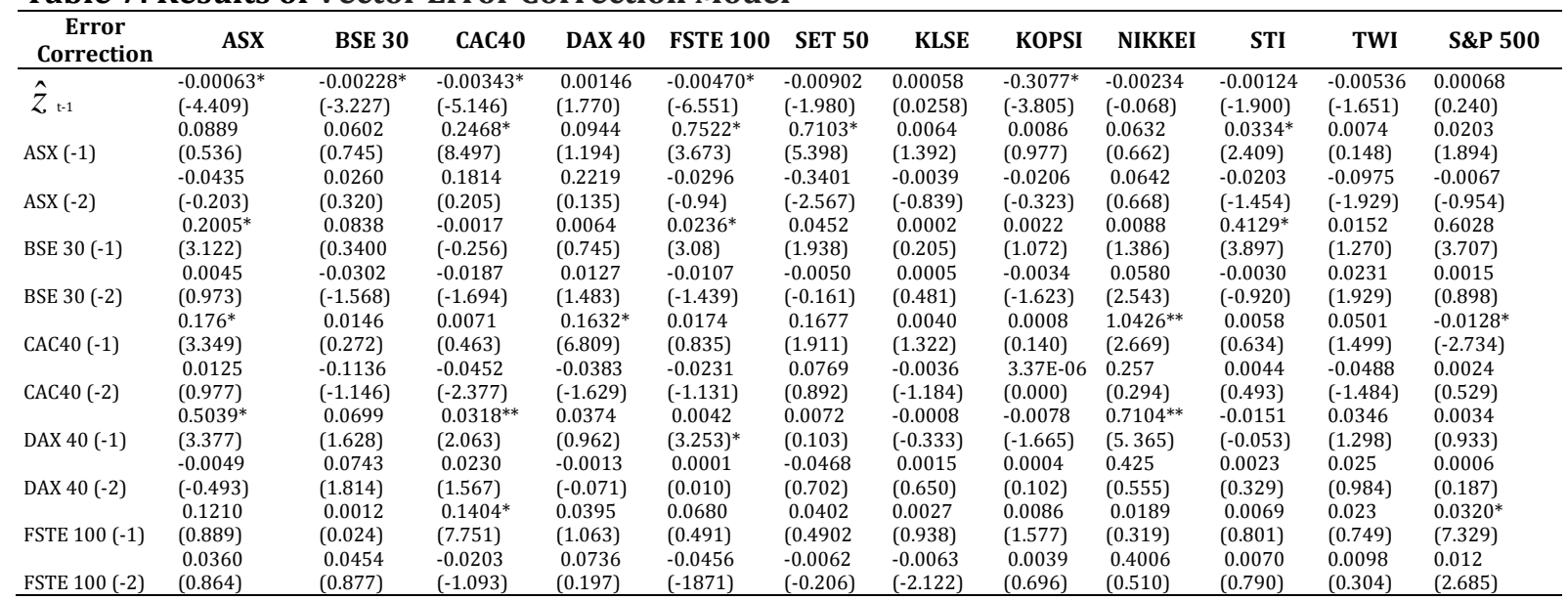

Notes: $\hat{z}$ t-1 represents the lagged error correction term. ${ }^{*}$ and ${ }^{* *}$ Indicates $1 \%$ and $5 \%$ level of significance. Figures in parentheses are $t$ values. Lag length is chosen based on Akaike Information Criterion (AIC) and Final Prediction Error

Table 7: (Continued)

\begin{tabular}{|c|c|c|c|c|c|c|c|c|c|c|c|c|}
\hline ECM: & ASX & BSE 30 & CAC40 & DAX 40 & FSTE & SET 50 & KLSE & KOPSI & NIKKEI & STI & TWI & S\&P 500 \\
\hline$\hat{z}_{\mathrm{t}-1}$ & $\begin{array}{l}-0.00063^{*} \\
(-4.409)\end{array}$ & $\begin{array}{l}-0.00228^{*} \\
(-3.227)\end{array}$ & $\begin{array}{l}-0.00343^{*} \\
(-5.146)\end{array}$ & $\begin{array}{l}0.00146 \\
(1.770)\end{array}$ & $\begin{array}{l}-0.0047^{*} \\
(-6.551)\end{array}$ & $\begin{array}{l}-0.00902 \\
(-1.980)\end{array}$ & $\begin{array}{l}0.00058 \\
(0.0258)\end{array}$ & $\begin{array}{l}-0.3077^{*} \\
(-3.805)\end{array}$ & $\begin{array}{l}-0.00234 \\
(-0.068\end{array}$ & $\begin{array}{l}-0.00124 \\
(-1.900)\end{array}$ & $\begin{array}{l}-0.00536^{*} \\
(-4.651)\end{array}$ & $\begin{array}{l}0.00068 \\
(0.240)\end{array}$ \\
\hline SET $50(-1)$ & $\begin{array}{l}0.0218^{*} \\
(7.479)\end{array}$ & $\begin{array}{l}0.0213 \\
(1.774)\end{array}$ & $\begin{array}{c}0.0073 \\
(1.696)\end{array}$ & $\begin{array}{c}0.0066 \\
(1.2497)\end{array}$ & $\begin{array}{l}0.0151^{*} \\
(3.252)\end{array}$ & $\begin{array}{l}0.0084 \\
(0.431)\end{array}$ & $\begin{array}{c}0.0001 \\
(0.207)\end{array}$ & $\begin{array}{r}0.0020 \\
(1.556)\end{array}$ & $\begin{array}{l}0.0060^{* *} \\
(2.423)\end{array}$ & $\begin{array}{l}0.0152^{*} \\
(7.375)\end{array}$ & $\begin{array}{l}0.0077 \\
(1.042)\end{array}$ & $\begin{array}{l}0.004^{*} \\
(2.176)\end{array}$ \\
\hline SET $50(-2)$ & $\begin{array}{l}-0.0025 \\
(-0.859)\end{array}$ & $\begin{array}{r}0.0080 \\
(0.660)\end{array}$ & $\begin{array}{r}0.0040 \\
(0.933)\end{array}$ & $\begin{array}{r}0.0113 \\
(0.092)\end{array}$ & $\begin{array}{r}0.0151 \\
(3.212)\end{array}$ & $\begin{array}{l}-0.0555 \\
(-2.7998\end{array}$ & $\begin{array}{l}-0.0016 \\
(-2.304)\end{array}$ & $\begin{array}{r}0.0003 \\
(0.251)\end{array}$ & $\begin{array}{c}0.0014 \\
(0.102)\end{array}$ & $\begin{array}{r}0.0038 \\
(1.855)\end{array}$ & $\begin{array}{l}0.0047 \\
(0.622)\end{array}$ & $\begin{array}{l}0.0018 \\
(2.715)\end{array}$ \\
\hline KLSE (-1) & $\begin{array}{l}0.0157^{*} \\
(2.194)\end{array}$ & $\begin{array}{l}0.17783 \\
(0.532)\end{array}$ & $\begin{array}{l}0.1942 \\
(1.619)\end{array}$ & $\begin{array}{l}0.11128 \\
(0.749)\end{array}$ & $\begin{array}{l}0.0304 \\
(0.235)\end{array}$ & $\begin{array}{l}0.0716 * * \\
(0.231)\end{array}$ & $\begin{array}{l}0.0720^{*} \\
(3.756)\end{array}$ & $\begin{array}{l}0.1943^{*} \\
(5.333)\end{array}$ & $\begin{array}{l}0.0416^{*} \\
(3.105)\end{array}$ & $\begin{array}{c}0.0352 \\
(0.615)\end{array}$ & $\begin{array}{l}0.0760 \\
(0.367)\end{array}$ & $\begin{array}{l}0.0433 \\
(1.496)\end{array}$ \\
\hline KLSE (-2) & $\begin{array}{l}0.17609 \\
(2.170)\end{array}$ & $\begin{array}{c}0.7634 \\
(2.2841\end{array}$ & $\begin{array}{r}0.1121 \\
(0.933)\end{array}$ & $\begin{array}{l}0.2442 \\
(1.643)\end{array}$ & $\begin{array}{l}-0.2854 \\
(-2.20)\end{array}$ & $\begin{array}{l}0.1229 \\
(0.225)\end{array}$ & $\begin{array}{c}0.0027 \\
(0.1433\end{array}$ & $\begin{array}{r}0.0411 \\
(1.128)\end{array}$ & $\begin{array}{c}0.3984 \\
(1.009)\end{array}$ & $\begin{array}{r}0.0009 \\
(0.016)\end{array}$ & $\begin{array}{l}0.0443 \\
(0.213)\end{array}$ & $\begin{array}{l}0.0598^{*} \\
(3.060)\end{array}$ \\
\hline KOPSI $(-1)$ & $\begin{array}{r}0.0722 \\
(1.644)\end{array}$ & $\begin{array}{l}0.3489 \\
(1.929)\end{array}$ & $\begin{array}{r}0.0840 \\
(1.292)\end{array}$ & $\begin{array}{l}0.0179 \\
(0.223)\end{array}$ & $\begin{array}{l}0.1219 \\
(1.743)\end{array}$ & $\begin{array}{l}0.2301 \\
(0.781)\end{array}$ & $\begin{array}{l}0.0086^{*} \\
(3.828)\end{array}$ & $\begin{array}{r}0.0143 \\
(0.728)\end{array}$ & $\begin{array}{l}0.2452 \\
(1.147)\end{array}$ & $\begin{array}{l}0.0952 \\
(0.067)\end{array}$ & $\begin{array}{l}0.0916 \\
(0.815)\end{array}$ & $\begin{array}{l}0.0360 \\
(2.995)\end{array}$ \\
\hline & -0.0834 & -0.0937 & -0.0096 & 0.1990 & 0.0733 & $0.9411 *$ & $\begin{array}{r}0.0372 \\
0.597\end{array}$ & -0.0350 & 0.0774 & 0.0147 & $0.2377^{* *}$ & 0.0153 \\
\hline KOPSI (-2) & & $\begin{array}{c}(-0.529) \\
0.0514\end{array}$ & $\begin{array}{c}(-0.148) \\
0.0047\end{array}$ & $\begin{array}{r}(1.484) \\
0.0184\end{array}$ & $\begin{array}{l}(1.053) \\
0.0139\end{array}$ & $\begin{array}{c}(3.207) \\
0.0378\end{array}$ & $\begin{array}{l}(0.597) \\
0.0003^{*}\end{array}$ & $\begin{array}{c}(-1.783) \\
0.0010\end{array}$ & $\begin{array}{l}(0.364) \\
0.0353\end{array}$ & & $\begin{array}{l}(2.124) \\
0.0023\end{array}$ & $\begin{array}{l}(0.980) \\
0.0023^{*}\end{array}$ \\
\hline NIKKEI (-1) & $(9.674)$ & (1.114) & $(0.507)$ & $(0.817)$ & (2.189) & (1.407) & $(3.350)$ & $(0.564)$ & (1.811) & (1.305) & $(0.153)$ & $(3.634)$ \\
\hline NIKKEI (-2) & $\begin{array}{r}0.0066 \\
(1.644)\end{array}$ & $\begin{array}{l}-0.0126 \\
(-0.760)\end{array}$ & $\begin{array}{r}0.0028 \\
(0.476)\end{array}$ & $\begin{array}{l}-0.0170 \\
(-1.315)\end{array}$ & $\begin{array}{r}0.0056 \\
(0.874)\end{array}$ & $\begin{array}{l}-0.0046 \\
(-0.172)\end{array}$ & $\begin{array}{l}-0.0004 \\
(-0.444)\end{array}$ & $\begin{array}{r}0.0020 \\
(1.135)\end{array}$ & $\begin{array}{l}-0.0256 \\
(-1.306)\end{array}$ & $0.0061^{* *}$ & $\begin{array}{l}0.0348 \\
(3.375)\end{array}$ & 0.0015 \\
\hline STI $(-1)$ & $\begin{array}{l}0.1433^{*} \\
(5.134)\end{array}$ & $\begin{array}{c}0.0593 \\
(0.515)\end{array}$ & $\begin{array}{l}0.1507^{*} \\
(3.646)\end{array}$ & $\begin{array}{l}-0.1217^{* *} \\
(-2.381)\end{array}$ & $\begin{array}{l}0.1420^{*} \\
(3.193)\end{array}$ & $\begin{array}{l}-0.2108^{*} \\
(-2.925)\end{array}$ & $\begin{array}{c}0.4061^{*} \\
(4.924)\end{array}$ & $\begin{array}{r}0.0043 \\
(0.350)\end{array}$ & $\begin{array}{l}0.2816^{* *} \\
(2.072)\end{array}$ & $\begin{array}{l}-0.0173 \\
(-0.877)\end{array}$ & $\begin{array}{l}0.1264 \\
(1.770)\end{array}$ & $\begin{array}{l}0.0143^{*} \\
(3.434)\end{array}$ \\
\hline STI $(-2)$ & $\begin{array}{r}0.0066 \\
(0.237)\end{array}$ & $\begin{array}{l}-0.0295 \\
(-0.2578\end{array}$ & $\begin{array}{r}0.0390 \\
(0.948)\end{array}$ & $\begin{array}{r}0.1398 \\
(2.744)\end{array}$ & $\begin{array}{l}-0.0409 \\
(-0.92)\end{array}$ & $\begin{array}{l}0.1582 \\
(0.847)\end{array}$ & $\begin{array}{r}0.0307 \\
(1.664)\end{array}$ & $\begin{array}{c}0.0159 \\
(1.277)\end{array}$ & $\begin{array}{r}0.0435 \\
(0.321)\end{array}$ & $\begin{array}{l}0.0198 \\
(1.011)\end{array}$ & $\begin{array}{l}-0.0977 \\
(-1.373)\end{array}$ & $\begin{array}{l}0.0173 \\
(1.746)\end{array}$ \\
\hline TWI $(-1)$ & $\begin{array}{r}0.0001 \\
(0.013)\end{array}$ & $\begin{array}{l}-0.0157 \\
(-0.509)\end{array}$ & $\begin{array}{r}0.0011 \\
(0.099)\end{array}$ & $\begin{array}{c}0.0068 \\
(0.496)\end{array}$ & $\begin{array}{l}-0.0052 \\
(-0.447)\end{array}$ & $\begin{array}{l}0.0933 \\
(1.857)\end{array}$ & $\begin{array}{r}0.0079 \\
(4.475)\end{array}$ & $\begin{array}{r}0.0018 \\
(0.550)\end{array}$ & $\begin{array}{l}-0.2020^{*} \\
(-4.057)\end{array}$ & $\begin{array}{l}0.00311 \\
(0.587)\end{array}$ & $\begin{array}{l}0.0277 \\
(1.449)\end{array}$ & $\begin{array}{l}0.0067^{*} \\
(2.506)\end{array}$ \\
\hline TWI (-2) & $\begin{array}{l}-0.0032 \\
(-0.437)\end{array}$ & $\begin{array}{l}-0.0124 \\
(-0.403)\end{array}$ & $\begin{array}{r}0.0089 \\
(0.804)\end{array}$ & $\begin{array}{l}-0.00152 \\
(-0.110)\end{array}$ & $\begin{array}{c}0.0023 \\
(0.197)\end{array}$ & $\begin{array}{l}-0.0165 \\
(-0.328)\end{array}$ & $\begin{array}{r}0.0077 \\
(1.384)\end{array}$ & $\begin{array}{l}0.0113^{*} \\
(3.374)\end{array}$ & $\begin{array}{c}0.0301 \\
(0.826)\end{array}$ & $\begin{array}{l}-0.0006 \\
(-0.117)\end{array}$ & $\begin{array}{l}0.0247 \\
(1.289)\end{array}$ & $\begin{array}{l}0.0023 \\
(0.875)\end{array}$ \\
\hline S\&P $500(-1)$ & $\begin{array}{c}0.2062 \\
(0.749)\end{array}$ & $\begin{array}{c}0.4149 \\
(1.831)\end{array}$ & $\begin{array}{l}0.1116^{*} \\
(3.370)\end{array}$ & $\begin{array}{c}0.3771^{*} \\
(3.743)\end{array}$ & $\begin{array}{l}0.2848^{*} \\
(3.250)\end{array}$ & $\begin{array}{l}0.0779 \\
(1.650)\end{array}$ & $\begin{array}{r}0.0090 \\
(0.694)\end{array}$ & $\begin{array}{l}-0.0109 \\
(0.941)\end{array}$ & $\begin{array}{l}0.1215^{* *} \\
(2.454)\end{array}$ & $\begin{array}{l}0.0983 \\
(0.024)\end{array}$ & $\begin{array}{l}1.0130 \\
(0.092)\end{array}$ & $\begin{array}{l}0.113 \\
(0.758)\end{array}$ \\
\hline S\&P $500(-2)$ & $\begin{array}{r}0.1253 \\
(0.295) \\
\end{array}$ & $\begin{array}{r}0.0393 \\
(0.175) \\
\end{array}$ & $\begin{array}{l}-0.0083 \\
(-0.443) \\
\end{array}$ & $\begin{array}{l}0.0016 \\
(0.31746)\end{array}$ & $\begin{array}{l}-0.0853 \\
(-0.9814)\end{array}$ & $\begin{array}{l}0.7275 \\
(1.989)\end{array}$ & $\begin{array}{c}0.2054^{*} \\
(3.4181)\end{array}$ & $\begin{array}{l}0.0491 \\
(-0.003)\end{array}$ & $\begin{array}{l}0.3976 \\
(1.4971)\end{array}$ & $\begin{array}{l}0.0561 \\
(1.455)\end{array}$ & $\begin{array}{l}0.2930 \\
(0.097)\end{array}$ & $\begin{array}{l}-0.0698 \\
(-1.578)\end{array}$ \\
\hline
\end{tabular}


Notes: $\hat{z}_{t-1}$ represents the lagged error correction term. ${ }^{*}$ and ${ }^{* *}$ Indicates $1 \%$ and $5 \%$ level of significance. Figures in parentheses are $t$ values. Lag length is chosen based on Akaike Information Criterion (AIC) and Final Prediction Error (FPE).

Finally, the study examines the effect of one unit innovation of other markets on BSE and vice versa through the impulse response function. The empirical results are presented in figures 1 to 11 . They reveal that most of the stock markets respond positively to own shocks rather than other shocks. In other words, the magnitude of response of most of the stock markets to their own shock and the shock from other markets is quite similar for all the markets. The results also show that the response of the BSE to a shock in the US market is positive rather than negative. However, the response of BSE to the US market is stronger than the response of the US market to the BSE. Finally, the results show that BSE stock returns are affected not only by own shocks, but also by shocks from other markets, such as the US stock market.

\section{Conclusion}

The study investigates the dynamic interlinkages between the Indian and the world's major developed stock markets. The daily closing prices of the S\&P 500 (US), FTSE 100 (the United Kingdom), DAX-30 (Germany), CAC-40 (France), the Nikkei 225 (Japan), SET 50 (Thailand), KOSPI (Korea), Kuala Lumpur Composite KLSE (Malaysia) and BSE (India) were collected from January 1998 to June 2010. The study employs the Johansen and Juselius co integration and Vector Error Correction Models to examine the short run and long run equilibrium relationships across international stock markets. The results also show a strong co integration relationship across international stock markets. These results proven that most of the stock price indices across world move together in the end. . In the whole, the weight of evidence in this paper is in favor of the conclusion that the US stock market dominates most of the international stock markets under investigate.

\section{References}

Al-Khazali, O., Darrat, A. F. \& Saad, M. (2006). Intra-regional Integration of the GCC Stock Markets: The Role of Market Liberalization. Applied Financial Economics, 16(7), 1265-1272.

Berben, R. P. \& Jansen, W. J. (2003). Co movement in International Equity Markets: a Sectoral View. Forthcoming in Journal of International Money and Finance, 3, 1-28.

Chan, C. K., Gup, B. E. \& Pan, M. S. (1992). An Empirical Analysis of Stock Prices in Major Asian markets and the US. Financial Review, 27(2), 289-307.

Cheung, C. S. \& Lee, J. (1993). Integration vs Segmentation in the Korean Stock Market. Journal of Business Finance and Accounting, 20(2), 267-73.

Cheung, Y. L. \& Mak, S. C. (1992). A Study of the International Transmission of Stock Market Fluctuation between the Developed Markets and Asian Pacific Market. Applied Financial Economics, 2(1), 4347.

Dickey, D. A. \& Fuller, W. A. (1979). Distribution of the Estimators for Autoregressive Time Series with a Unit Root. Journal of the American Statistical Association, 74(3), 427-431.

Engle, P. \& Granger, S. (1987). Co-integration and Error Correction: Representation, Estimation, and Testing. Econometrica, 55(2), 251-76.

Errunza, V. (1985). Gains from Portfolio Diversification into Less Developed Countries' Securities. Journal of International Business Studies, 8(2), 83-99.

Johansen, S. \& Juselius, K. (1990). Maximum Likelihood Estimation and Inference on Co integrations to the Demand for Money. Oxford Bulletin of Economics and Statistics, 52(4), 169-210.

Hansda, S. K. \& Ray, P. (2003). Stock Market Integration and Dually Listed Stocks: Indian ADR and Domestic Stock Prices. Economic and Political Weekly, 12(3), 741-753.

Hilliard, J. (1979). The Relationship between Equity Indices on World Exchanges. Journal of Finance, 8(5), 103-114.

Masih, A. M. M. \& Masih, R. (1997a). A Comparative Analysis of the Propagation of Stock Market Fluctuations in Alternative Models of Dynamic Causal Linkages. Applied Financial Economics, $7(3), 59-64$.

Masih, A. M. M. \& Masih, R. (1999). Is Asian Stock market Fluctuations due Mainly to Intra-regional Contagion Effects? Evidence based on Asian Emerging Stock Markets. Pacific-Basin Finance Journal, 7 (4), 251-82.

Phillips, P. C. B \& Perron, P. (1988). Testing for a Unit Root in Time Series Regression. Biometrika, 75, 335-346. 
Rao, B. S. R. \& Naik, U. (1990). Inter-Relatedness of Stock Markets: Spectral Investigation of USA, Japanese and Indian Markets - A Note. Arth Vignana, 32(3\&4), 309-321.

Suchismita, B. \& Paramita, M. (2005). A Study of Interlikings between the Indian Stock Market and other Emerging and Developed Market. World Economic Outlook, IMF, 1-13.

Segot, T. L. \& Lucey, B. M. (2005). Capital Market Integration in the Middle East and North Africa and its Implications for International Portfolio Allocation. IIIS Discussion Paper, 71(3), 1-32.

Von-Furstenberg, G. M. \& Jeon, B. N. (1989). International Stock Price Movements: Links and Messages. Brooking Papers on Economic Activity, 1(1), 125-167.

Wong, W. K., Agarwal, A. \& Du, J. (2005). Financial Integration for India Stock Market: a Fractional Co integration Approach. Working Paper No. 0501, 1-29.

Zubaidi, B. A., Tamat, S. \& Boon, T. H. (2003). Dynamic Interrelationship among the Major Stock Market. Journal of the Asia Pacific Economy, 8(2), 180-209.

Figure1: Impulse Response Function between BSE 30 Sensex and FTSE 100 Returns

Response to Cholesky One S.D. Innovations
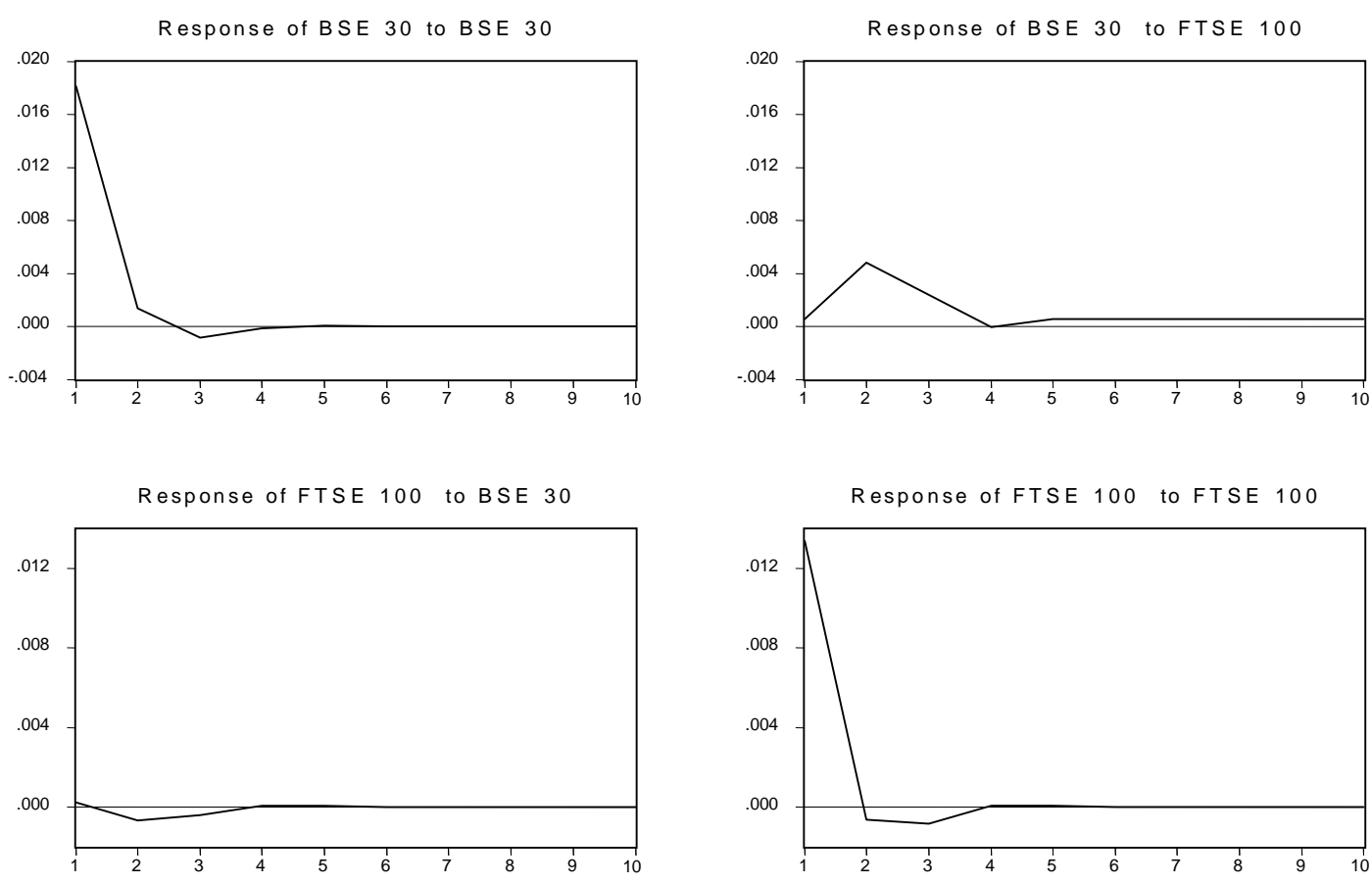
Figure 2: Impulse Response Function between BSE 30 Sensex and SET 50 Index Returns

Response to Cholesky One S.D. Innovations
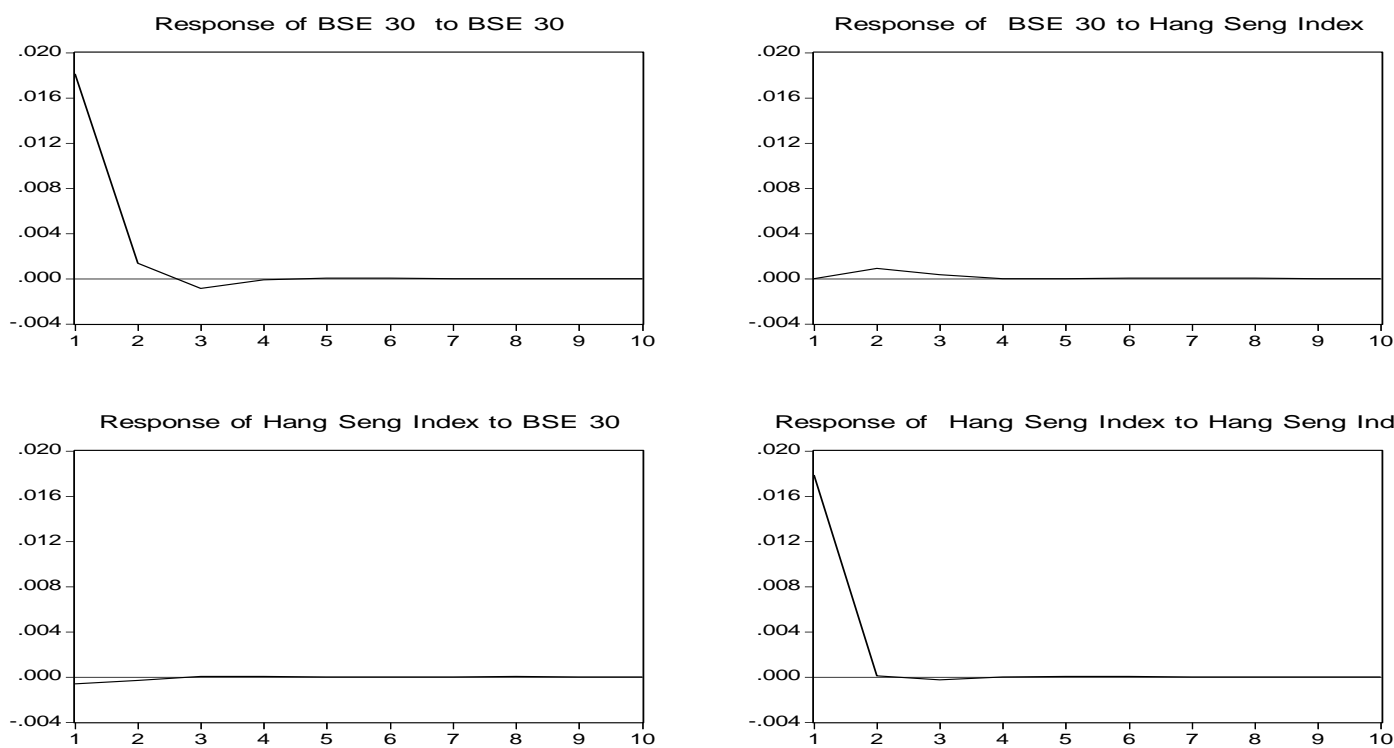

Response of Hang Seng Index to Hang Seng Index

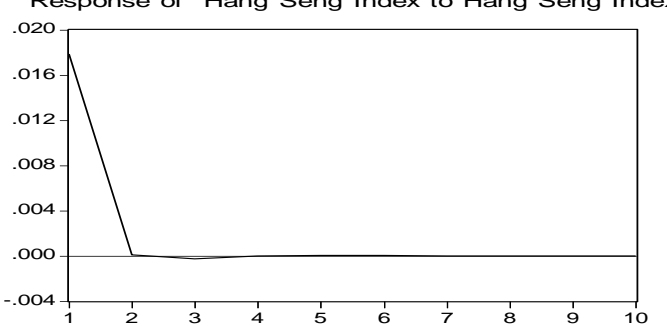

Figure 3: Impulse Response Function between BSE 30 Sensex and KOSPI Returns

Response to Cholesky One S.D. Innovations
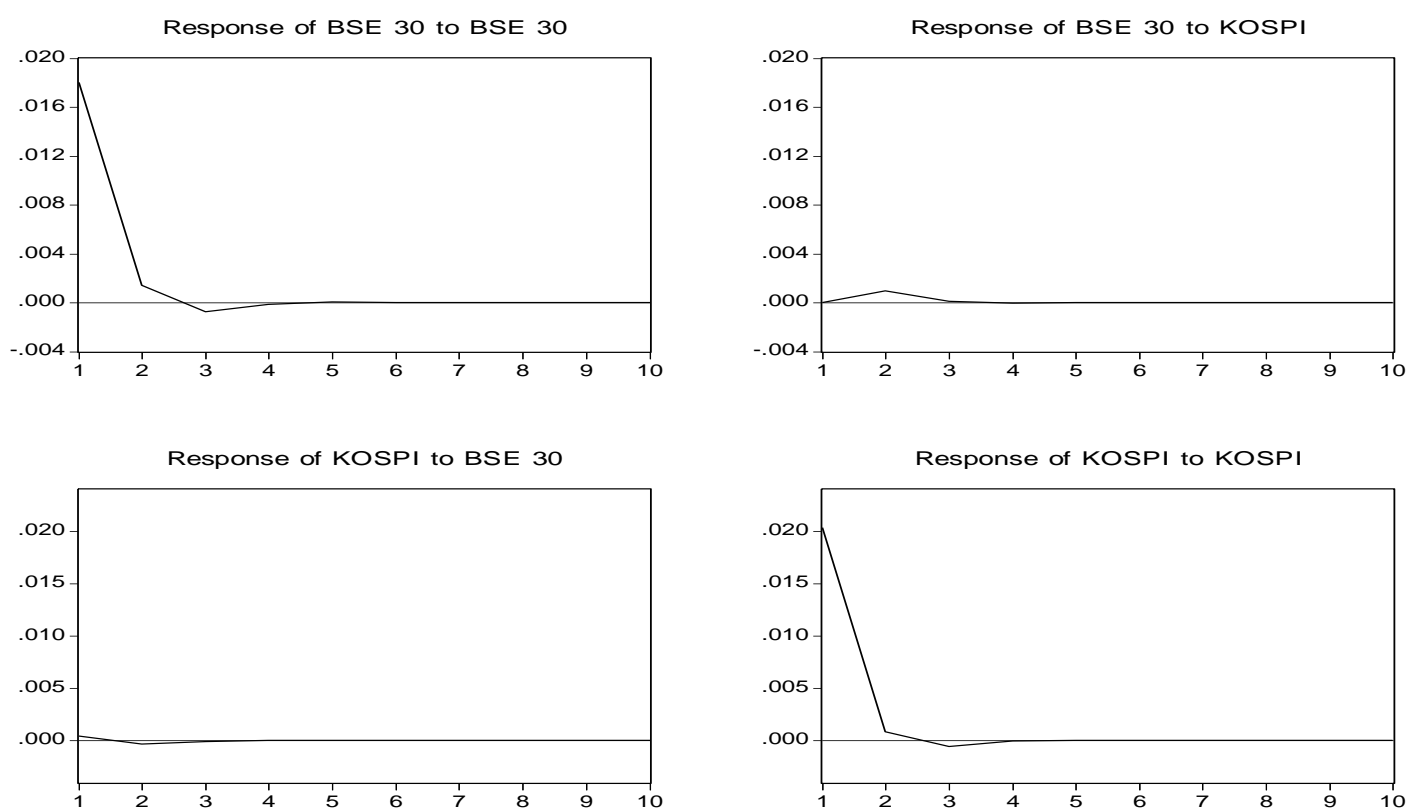
Figure 4: Impulse Response Function between BSE 30 Sensex and Nikkei 225 Returns

Response to Cholesky One S.D. Innovations
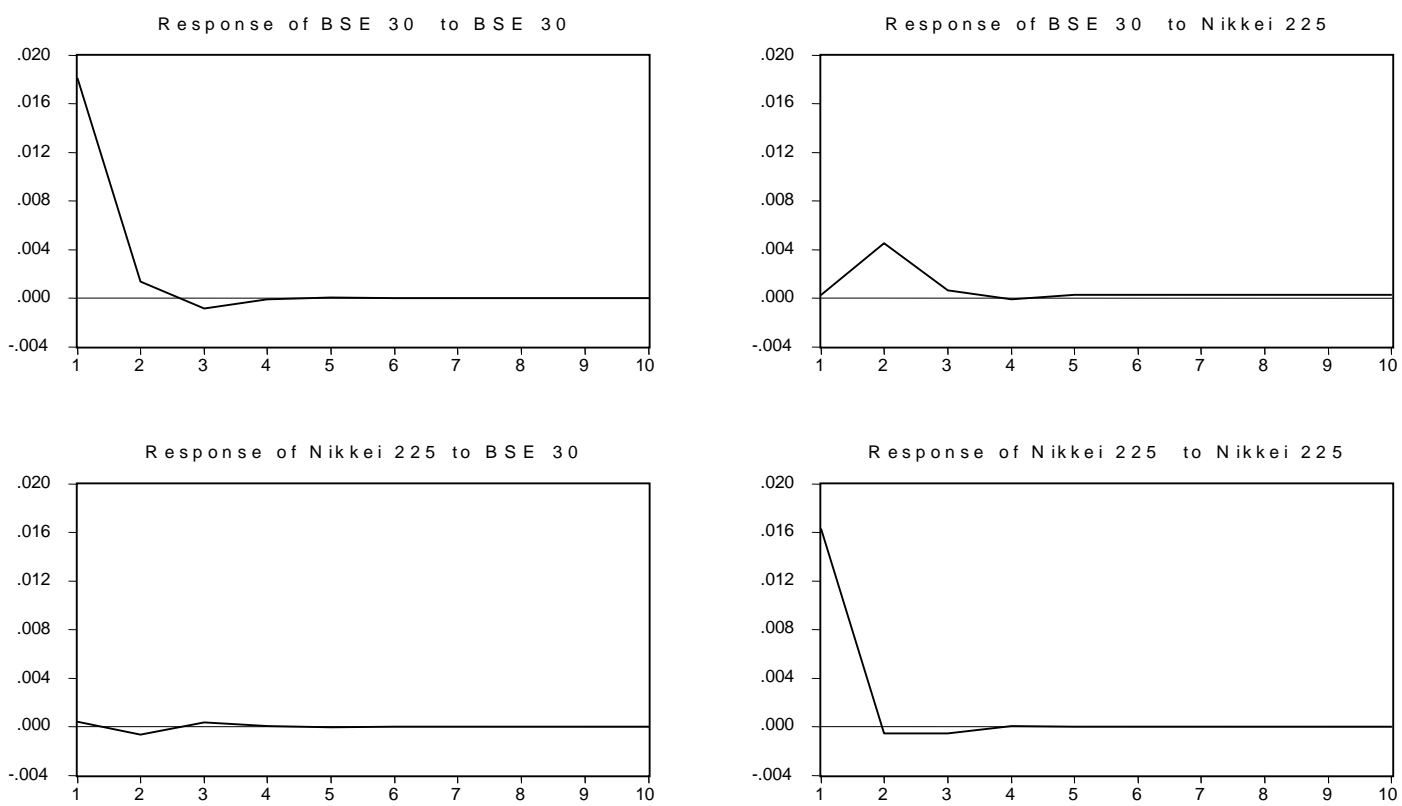

Figure 5: Impulse Response Function between BSE 30 Sensex and Strait Times Index Returns

Response to Cholesky One S.D. Innovations
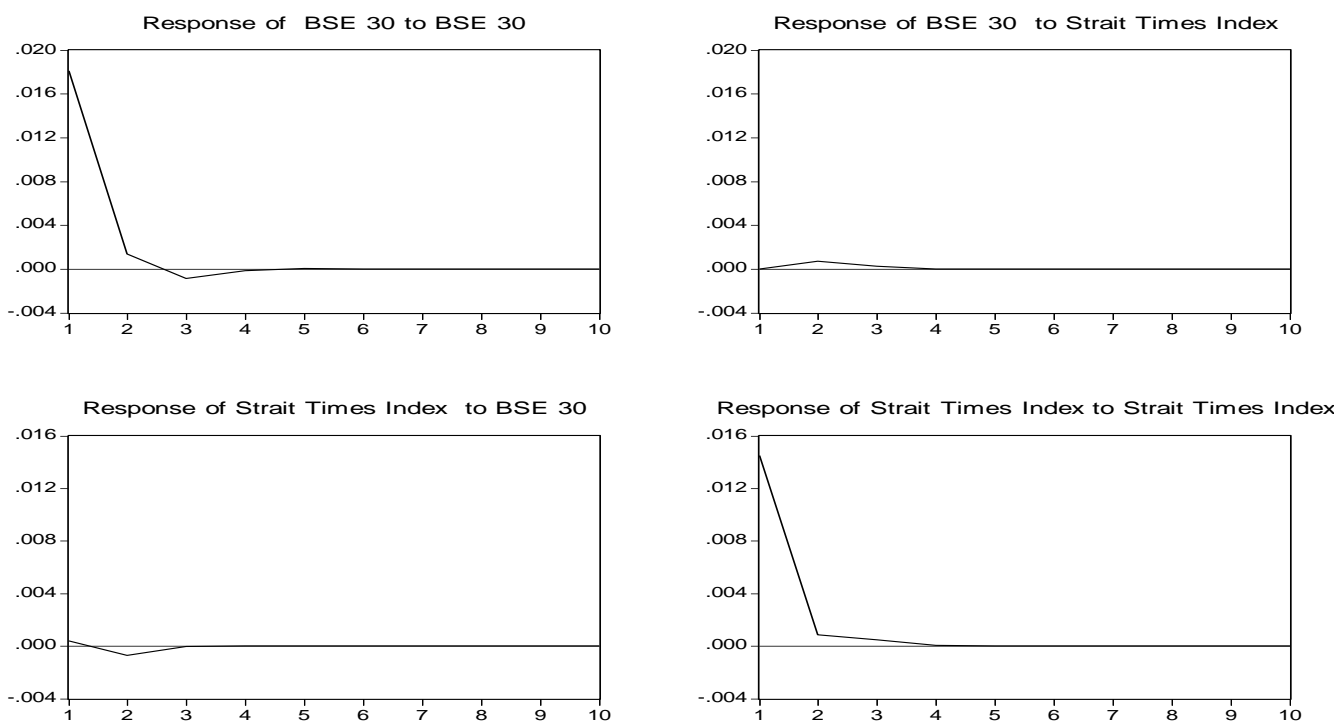
Figure 6: Impulse Response Function between BSE 30 Sensex and Taiwan Weighted Index Returns

Response to Cholesky One S.D. Innovations
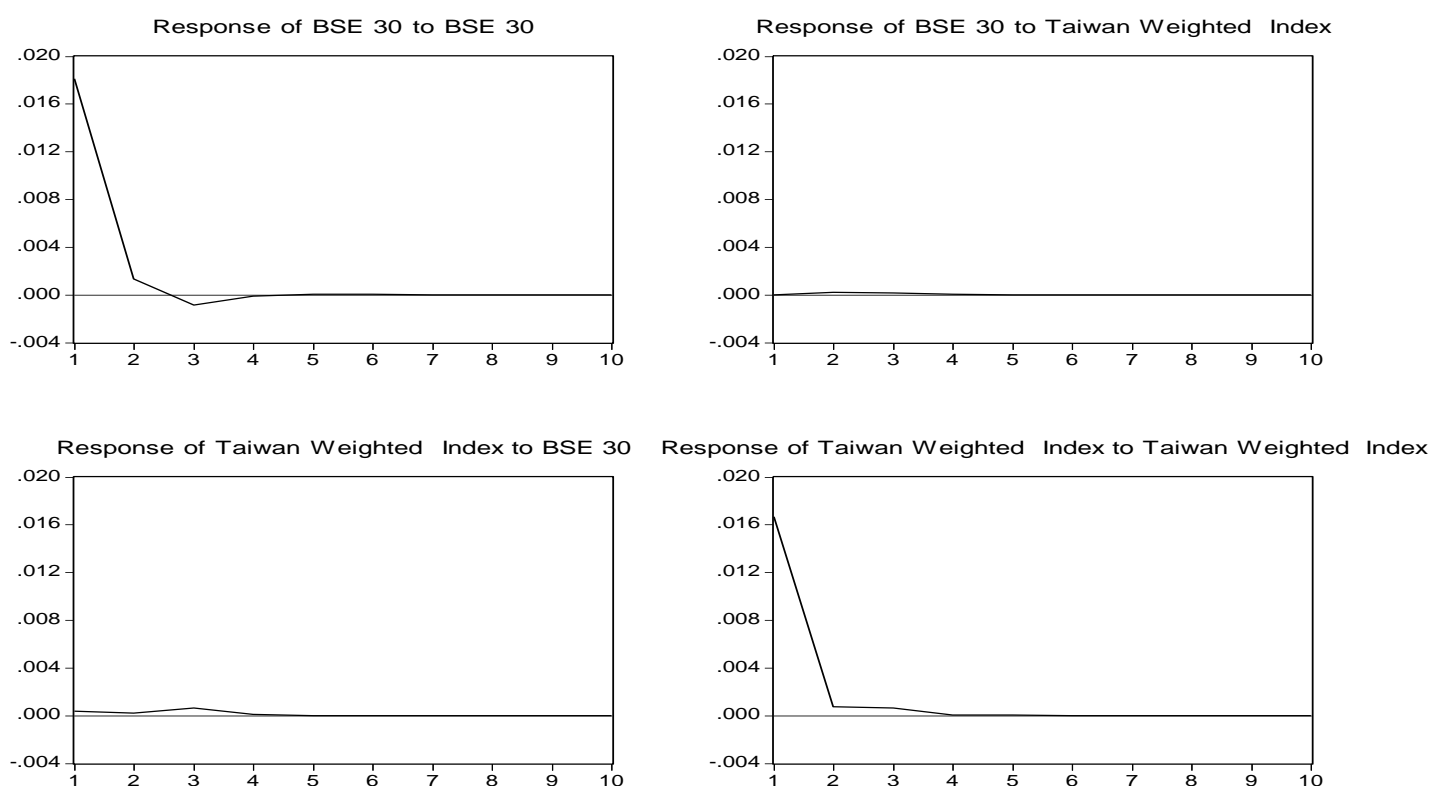

Figure 7: Impulse Response Function between BSE 30 Sensex and All Ordinaries Shares Returns

Response to Cholesky One S.D. Innovations
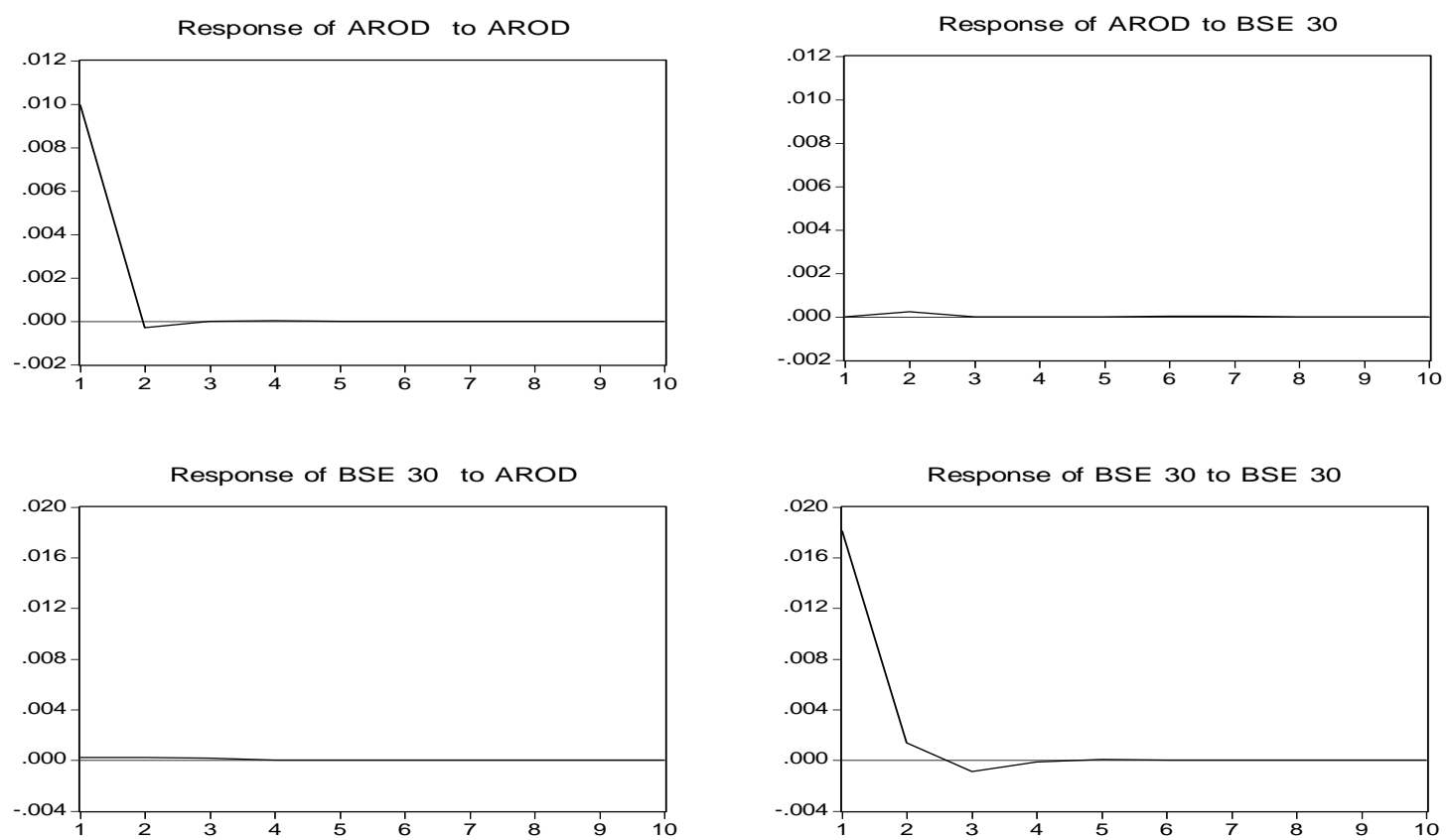
Figure 8: Impulse Response Function between BSE 30 Sensex and CAC-40 index Returns

Response to Cholesky One S.D. Innovations
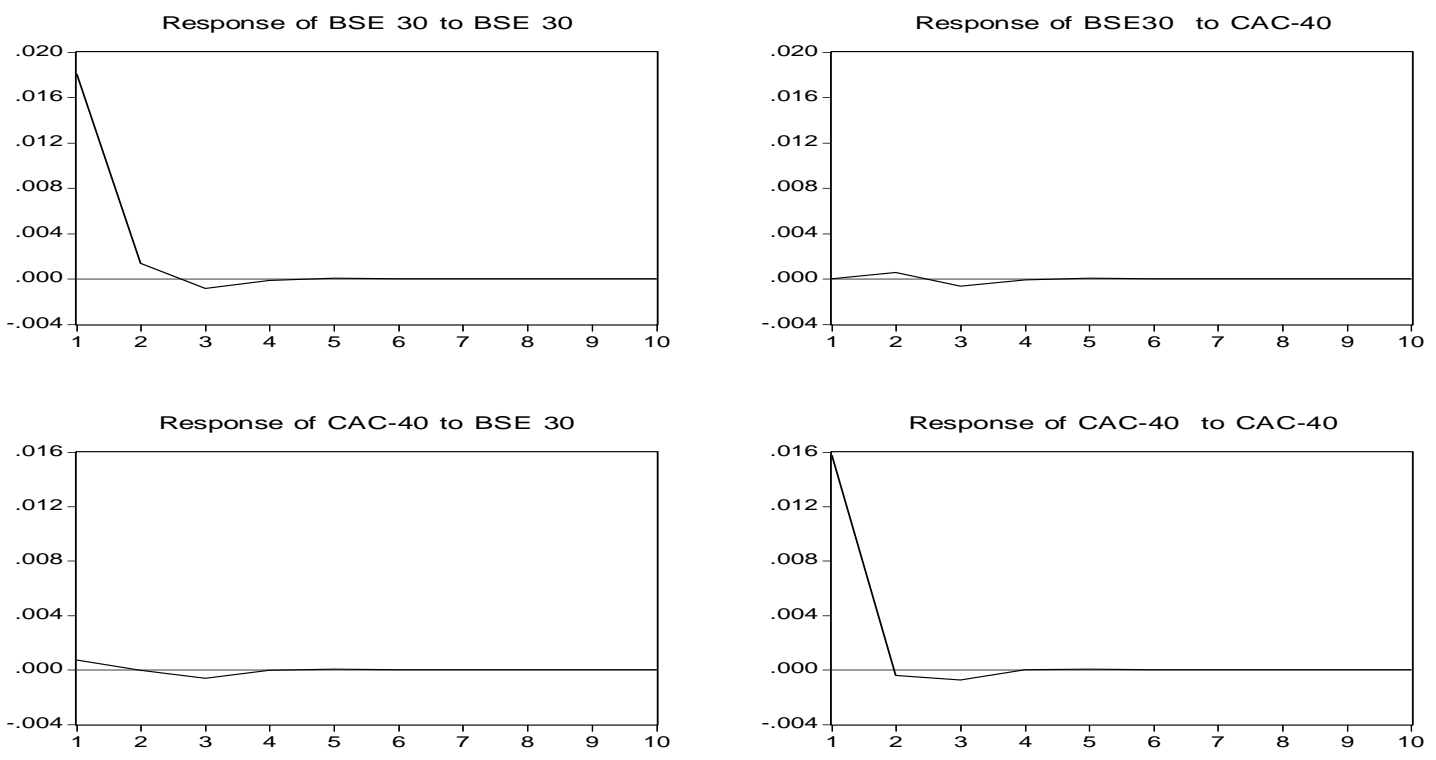

Figure 9: Impulse Response Function between BSE 30 Sensex and S\&P500 index Returns

Response to Cholesky One S.D. Innovations
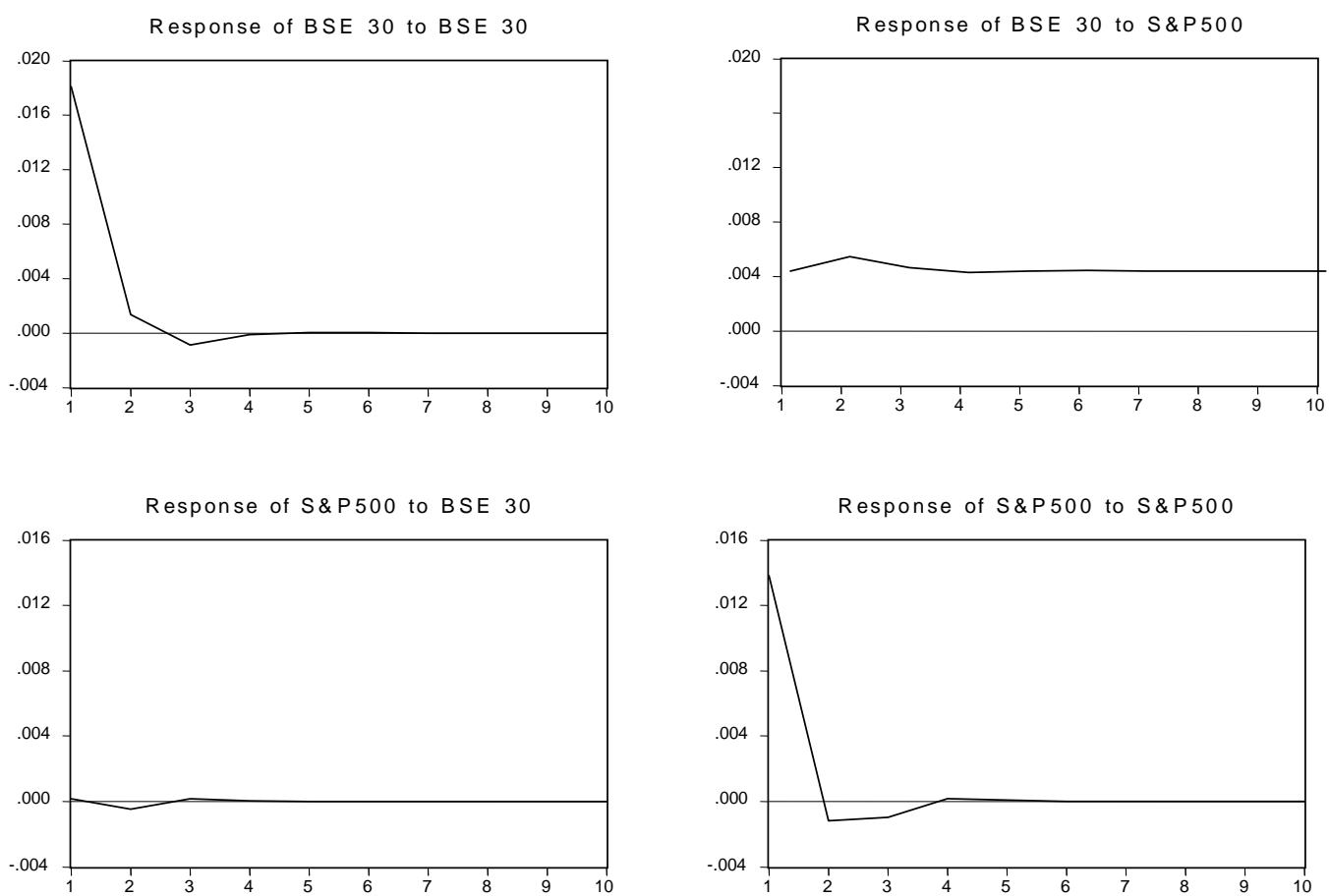
Figure 10: Impulse Response Function between BSE 30 Sensex and DAX 30 index Returns

Response to Cholesky One S.D. Innovations
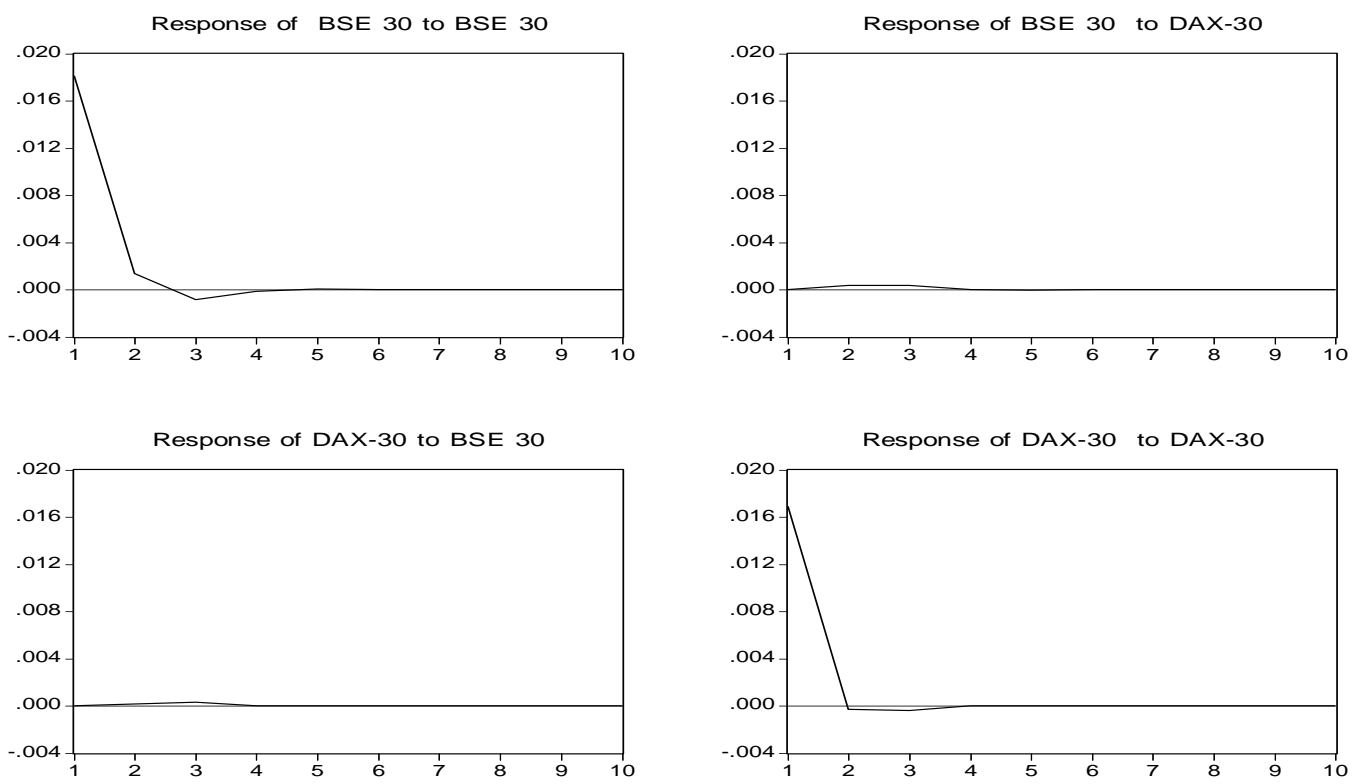

Figure 11: Impulse Response Function between BSE 30 Sensex and Kuala Lumpur Composite Returns

Response to Cholesky One S.D. Innovations
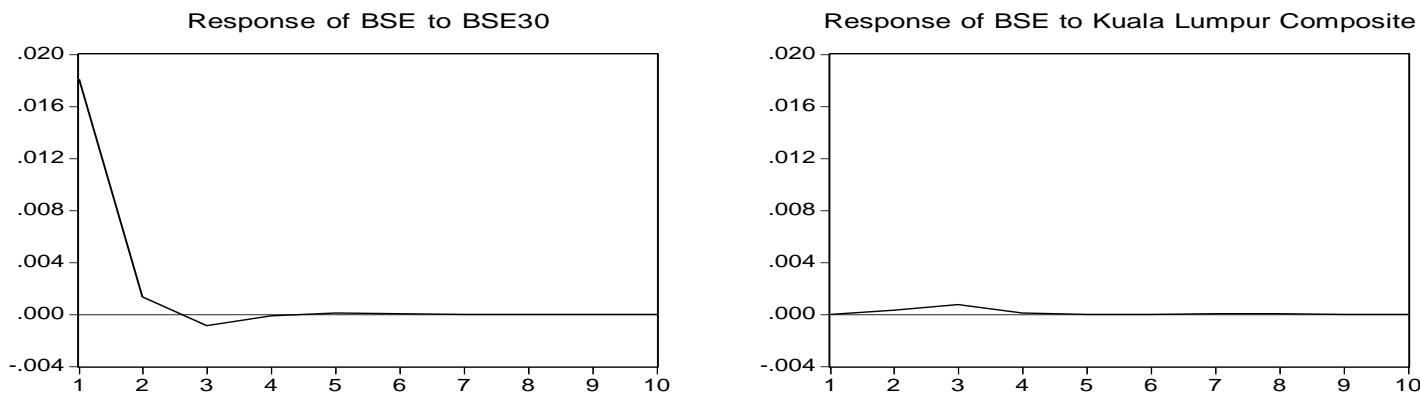

Response of Kuala Lumpur Composite to BSE 30 Response of Kuala Lumpur Composite to Kuala Lumpur Composite
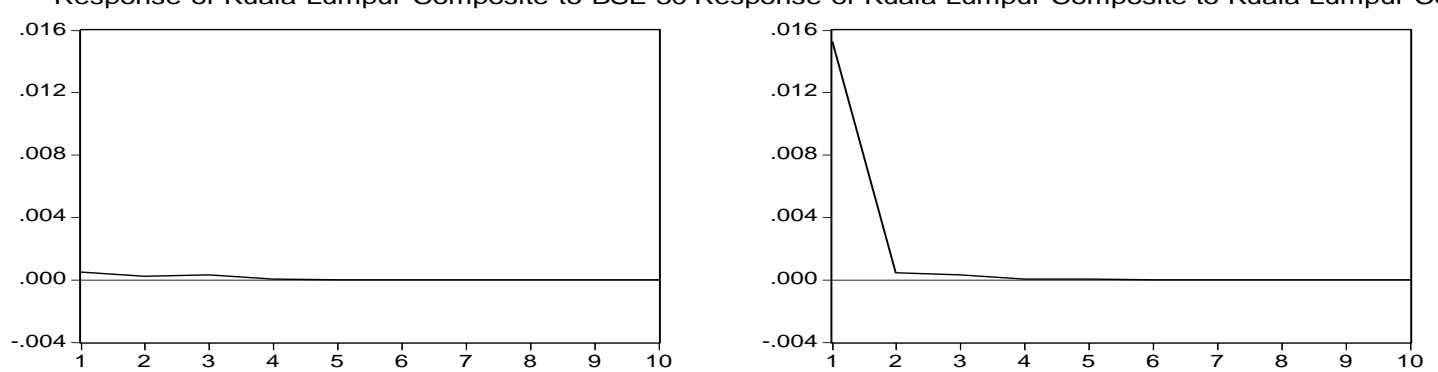